\title{
„ZA NIM ROSNĄCE PÓJDĄ PLEMIONA / W ŚWIATŁO - GDZIE BÓG". „SŁOWIAŃSKI” PONTYFIKAT ŚW. JANA PAWŁA II
}

Temat słowiański i jego rola w pontyfikacie św. Jana Pawła II został opracowany w książce Ryszarda Łużnego (Łużny), którą można określić jako - dokonaną z rozmachem i wnikliwością - hermeneutykę nauczania św. Jana Pawła II w jego wymiarze religijnym i społecznym. Wcześniej, w 1997 roku, opublikowane zostały materiały wygłoszone przez specjalistów od Słowiańszczyzny podczas sympozjum w Castel Gandolfo (Bobrownicka, Suchanek i Ziejka), które stanowią ledwie skromny wycinek komentarzy na temat papieskiej myśli i twórczości literackiej ${ }^{1}$. Zaproponowana przez Organizatorów formuła konferencji z inicjalnym pytaniem: „,zy daleko jeszcze do źródła?" - skłania do ponownej refleksji nad powyższymi, wydawałoby się, już opracowanymi problemami. Z perspektywy czasu widać coraz wyraźniej wypełnianie się proroctwa św. Jana Pawła II, zwłaszcza dotyczącego zagrożeń dla kulturowej tożsamości Słowiańszczyzny, które przyniósł rozwój cywilizacyjny i polityczne zjednoczenie Europy. Można w tym miejscu zaryzykować twierdzenie, że określenie rodziny narodów słowiańskich, jeszcze niedawno naturalne, dziś znika z dyskursu społecznego, tak jak umiera pamięć o kulturze i przeszłości tej części Europy, a jej języki narodowe są spychane przez współczesną „łacinę” na margines komunikacji.

Obawy Papieża zostały zaprezentowane szczególnie wyraźnie w książce Pamięć i tożsamość. Formułowane u progu dwudziestego pierwszego wieku i opublikowane

Prof. dr hab. AgNiESZKa CZAJKowsKa - profesor Instytutu Literaturoznawstwa UHP im. JD; adres do korespondencji: Wydział Humanistyczny Uniwersytetu Humanistyczno-Przyrodniczego im. Jana Długosza w Częstochowie, al. Armii Krajowej 36a; e-mail: a.czajkowska@ujd.edu.pl. ORCID: http:// orcid.org/0000-0001-8448-023X.

${ }^{1}$ Ważniejsze teksty na temat pisarstwa Karola Wojtyły gromadzi praca Dybciaka Pisarstwo Karola Wojtyły. Znajduje się tu m.in. tekst Stanisława Dziedzica (Dziedzic), który ukazuje związki poezji Papieża z tradycją słowiańską. Na temat motywów słowiańskich w twórczości Jana Pawła II zob. także Taras. 
w roku śmierci sądy Jana Pawła II stanowią wszechstronne podsumowanie jego doświadczeń. Należy je odczytywać jako testament Świętego i przede wszystkim jako wyraz zawierzenia Bogu losów świata.

Wypowiedzi zapisane w Pamięci i tożsamości są zgodne z papieską nauką, którą zawsze cechowało obfite czerpanie z własnych doświadczeń, sięganie do dziejów narodowej wspólnoty, przywoływanie doświadczeń historii. Jan Paweł II stale umieszczał człowieka w perspektywie transcendentnej, odnosząc jego działania do porządku wiary. Te w pełni ludzkie świadectwa i zdarzenia w Pamięci i tożsamo$s ́ c i$ są odczytywane poprzez rzeczywistość biblijną i współtworzą dokonywaną na stronach książki diagnozę współczesności.

W wydanym w 2005 roku rozrachunku Papież formułował swoje obawy związane z przemianami w krajach słowiańskich, które nastąpiły po 1989 roku:

Dzisiaj obie części Europy - zachodnia i wschodnia - ponownie się zbliżają. To zjawisko, samo w sobie jak najbardziej pozytywne, nie jest pozbawione ryzyka. Wydaje mi się, że podstawowym zagrożeniem dla Europy Wschodniej jest jakieś przyćmienie własnej tożsamości. [...] Na czym wobec tego polega ryzyko? Polega ono na bezkrytycznym uleganiu wpływom negatywnych wzorców kulturowych rozpowszechnionych na Zachodzie. (Pamięć i tożsamość 148)

Słowiański Papież zagrożenie upatrywał w unifikacji kulturowej, która przyćmiewała, jak to określał, tożsamość narodów Europy Wschodniej. Czuł się jej częścią i wyraźnie zaznaczał jej swoistość na tle innych nacji.

Źródło obserwowanej odmienności narodów słowiańskich i „Zachodnioeuropejskich" Jan Paweł II widział w dziejach duchowych kontynentu. Przykładem ilustrującym to zjawisko był w Pamięci i tożsamości dokonany w XVII wieku przewrót kartezjański, którego skutkiem okazała się całkowita zmiana w rozumieniu kondycji ludzkiej. Podkreślając pozytywny wpływ epoki świateł na dzieje cywilizacji europejskiej, Papież ujawniał również zło, którego źródłem stała się filozofia oświeceniowa. Najważniejszą zmianą, jaką francuscy myśliciele wprowadzili do rozumienia istoty człowieka, było przekonanie o pierwszeństwie rozumu nad stworzeniem. Kartezjańskie Cogito ergo sum zamiast prymatu esse, czyli przekonania o człowieku jako stworzeniu bożym, wprowadzało, jak pisze Papież, dominację cogito, jako jedynego wyznacznika ludzkiego istnienia. Pisze Jan Paweł II:

Wcześniej wszystko było interpretowane przez pryzmat istnienia (esse) i wszystko się przez ten pryzmat tłumaczyło. Bóg jako samoistne Istnienie (Ens subsistens) stanowił nieodzowne oparcie dla każdego ens non subsistens, ens participatum, czyli dla wszystkich bytów stworzonych, a więc także dla człowieka. Cogito, ergo sum przyniosło zerwanie z tamtą tradycją myśli. Pierwotne stało się teraz ens cogitans (istnienie myślące). Od Kartezjusza filozofia staje się nauką czystego myślenia: wszystko to, co jest bytem (esse) - zarówno świat stworzony, jak i Stwórca - pozostaje w polu Cogito jako treść ludzkiej świadomości. (Pamięć i tożsamość 17) 
Cytowane uwagi, prócz tego, że definiowały źródło odejścia człowieka od Boga, to posłużyły do oznaczenia kulturowej odrębności Polaków - przedstawicieli Słowian. Papież określił ją przypominając recepcję encykliki Dominum et vivificantem. Opublikowany 18 maja 1986 roku dokument ukazywał rolę Ducha Świętego w życiu Kościoła i świata. Pamięć i tożsamość przedstawia nieprzychylne odgłosy, jakie encyklika w chwili wydania wywołała w Europie Zachodniej. Pisze Jan Paweł II:

Kiedy ukazała się encyklika o Duchu Świętym, pewne środowiska na Zachodzie bardzo negatywnie na nią zareagowały. Z czego wynikała ta reakcja? Pochodziła ona z tych samych źródeł, z których przed ponad dwustu laty zrodziło się tak zwane europejskie oświecenie - w szczególności oświecenie francuskie, nie wykluczając jednak angielskiego, niemieckiego, hiszpańskiego czy włoskiego. Od nich wszystkich różniło się oświecenie w Polsce. (Pamięć i tożsamość 16)

W cytowanym fragmencie kluczowe wydaje się stwierdzenie, iż recepcja prądów oświeceniowych nad Wisłą znacząco różniła się od tej w innych krajach². Ta swoista odmowa przyjęcia nowej filozofii stała się fundamentem kulturowej odmienności Polaków.

Jej wyrazem jest Pamięć $i$ tożsamość z tak wyraźnie podkreślaną chrześcijańską formacją i przywiązaniem do tradycji narodowych. W książce, podobnie jak w całym papieskim nauczaniu, Chrystus jest Zbawicielem konkretnego człowieka - z jego historią, pamięcią, osobowością i równie ważną przynależnością narodową. Dlatego też kategoria nacji była podczas homilii wypowiadana przez Świętego z dumą. Kontrastuje to wyraźnie z dzisiejszym skrępowaniem i nowoczesną wstydliwością, które wynikają z dyktatu racjonalności oraz przekonania o umownym pochodzeniu praw człowieka. Wspólnota ludzi związanych przez język i historię, wyrażająca się w kulturze, dziś zastępowana pojęciem społeczeństwa, dla Papieża była naturalnym środowiskiem każdego człowieka (Pamięć i tożsamość 74), jego domem, rodzajem matecznika.

Jan Paweł II jest w tym myśleniu mocno zakorzeniony w XIX wieku. Na jego formację duchową wielki wpływ miała tradycja polskiej literatury romantycznej,

\footnotetext{
${ }^{2} \mathrm{Na}$ ten temat warto w tym miejscu przytoczyć sądy Jarosława Marka Rymkiewicza, który w swoich esejach penetruje problemy „ducha polskiego”. W jego interpretacji niezdolność Polaków do królobójstwa i ich swoista polityczna niedojrzałość wynikały z niedostatecznego przyswojenia idei francuskiego oświecenia. Pisze o tym w książce zatytułowanej Wieszanie: „Czy gdyby Polacy w ostatnich dniach sierpnia 1794 roku powiesili pod kościołem Bernardynów [...] króla, który ich zdradził, dzieje insurekcji potoczyłyby się jakoś inaczej? [...] Polacy wtedy mogli stać się innym narodem” (26). Pisze dalej: „Z wszystkich korzyści, które sobie tu można wyobrazić, korzyścią najważniejszą byłoby powieszenie Stanisława Augusta Poniatowskiego. [...] Naród ufundowałby się na tym morderstwie - stałby się przez ten czyn groźnym i dzikim narodem królobójców - i ten czyn dziki i straszny uczyniłby Polaków [...] narodem nowoczesnym - idącym przez krew ku swoim nowym przeznaczeniom”. (227)
} 
ujmowanej nie tylko jako przejaw specyficznej estetyki czy związanej z nią tematyki, ale jako sposób myślenia o tożsamości narodowej i jej roli w dziejach powszechnych.

Swoją przynależność narodową słowiański Papież rozumiał jako dar i zarazem zobowiązanie. Stanowiły o niej zarówno jedność losów historycznych, jak i tradycje domowego, religijnego wychowania. Karol Wojtyła, ujmując naród jako społeczność żyjącą w czasie, widział ją w kontekście całej rodziny słowiańskiej. Dzieje tej wspólnoty przedstawiał poprzez włączenie jej w uniwersalny porządek Zbawienia. Akcentował bliskość naszych języków, kultur i losów dziejowych, podkreślał także powagę i zbieżność w czasie chrztów poszczególnych narodów Europy Środkowej i Wschodniej, które stały się momentami inicjalnymi dla organizacji państwowych i świadomie przeżywanych dziejów. Mówił na Wzgórzu Lecha 3 czerwca 1979 roku:

Trzeba, ażeby przy sposobności chrztu Polski była przypomniana chrystianizacja Słowian: Chorwatów i Słoweńców, wśród których pracowali misjonarze już około 650 r. [...] Bułgarów, których książę Borys I przyjął chrzest w 864 lub 865 r., Morawian i Słowaków - do nich docierali misjonarze przed 850 r., a potem umocnili tam wiarę święci apostołowie Słowian: Cyryl i Metody, [...] Czechów, których księcia Bořivoja ochrzcił w 874 r. św. Metody. [...] W zasięgu działalności św. Metodego i jego uczniów znajdowali się także Wiślanie oraz Słowianie zamieszkujący Serbię. Trzeba też, aby był przypomniany chrzest Rusi w Kijowie w 988 r. [...] trzeba przypomnieć ewangelizację Słowian Połabskich: Obodrytów [...] Wieletów i Serbołużyczan. [...] Papież Jan Paweł II - Słowianin, syn narodu polskiego, czuje, jak głęboko wrastają w glebę historii korzenie, z których on sam razem z wami wyrasta. (Pielgrzymki 37)

Papież w przemówieniu wygłoszonym na symbolicznym prasłowiańskim miejscu przypominał więc dokonaną $\mathrm{w}$ niemal jednakowym czasie przez rodzinę narodów inicjację w historię połączoną z dziejami Zbawienia. Czuł się dziedzicem tych wydarzeń i odkrywał ich istotność w przeszłości i we współczesnym świecie. Określał je jako misję Słowian, których, jak wielokrotnie podkreślał, reprezentował na tronie Piotrowym. Jan Paweł II był w tym myśleniu mocno osadzony w polskiej kulturze XIX wieku, w której temat słowiański był jednym z głównych wątków. Jednak ożywienie go - nawet bez uwzględnienia ówczesnych podziałów w Europie - niosło za sobą konieczność duchowego przezwyciężenia i intelektualnego zagospodarowania całego kompleksu problemów związanych z dziewiętnastowiecznym poczuciem polskiej tożsamości narodowej, jej zagrożeniem niesionym przez ideologię panslawizmu oraz, przede wszystkim, z żywą pamięcią o eksterminacji Polaków, której dokonywał wyposażony w barbarzyńską mentalność i polityczną siłę carat. Papież-poeta w swojej refleksji okazał się nie tylko wnikliwym czytelnikiem Mickiewicza, który w prelekcjach paryskich objaśnił i ukazał znaczenie Słowiańszczyzny dla przyszłości kontynentu. Jan Paweł II podjął wieszczy ton, oczyszczając go z doraźnych naleciałości - sytuacja emigracji, pamięć o encyklice Cum primus, 
w której Grzegorz XVI potępiał dążenie niepodległościowe Polaków oraz towianizm (Weintraub 420) - i odnajdując w nim autentycznie chrześcijańską „strunę światła”. Swoje zakorzenienie w kulturze romantyzmu posadowił na fundamencie wspólnoty dziejów Słowian i przejawianej przez nich religijności.

Na obecność kulturowej spuścizny XIX wieku w twórczości Karola Wojtyły zwracali uwagę liczni jej komentatorzy. Katalog pokrewieństw i poetyckich zależności w jego dziełach jest bardzo bogaty, sygnalizował je już u progu pontyfikatu Krzysztof Dybciak (Dybciak, Karol Wojtyła). Papież sam niejednokrotnie ujawniał zaciągnięty dług, odnosząc się do twórczości Cypriana Norwida, Juliusza Słowackiego, Adama Mickiewicza, a z poetów późniejszych - do Stanisława Wyspiańskiego. Należy jednak podkreślić, że duchowa wspólnota Papieża z polską poezją narodową, przejawiająca się w literackich aluzjach, częstym przywoływaniu nazwisk twórców i cytowaniu fragmentów wierszy (również w homiliach), ma swoje zakorzenienie także w refleksji historycznej, pozwalającej wiązać losy przodków i potomków w jedną nić i odczytywać koleje pojedynczego życia w utrwalonych formach egzystencji zbiorowej. Romantyczny spadek, z którego zdaje sprawę słowiański Papież, to również wspólna przestrzeń myśli i pojęć, złoża dziewiętnastowiecznej filozofii, kształtującej widzenie świata oraz odczytane z dziewiętnastowiecznych wierszy, jak z testamentu, zadanie poszukiwania godności człowieka w sferze ducha, nie w materii.

Polscy romantycy, intelektualni sukcesorzy kultury oświecenia, naznaczeni stygmatem rewolucyjnego przewrotu we Francji, ale też świadkowie nagłego przyspieszenia cywilizacyjnego, jaki miał miejsce w ówczesnej Europie, zostali pozbawieni państwa - formy organizacji społecznej i widzialnej postaci trwania narodu. W tej sytuacji musieli wykonać umysłową pracę, która pozwoliłaby na uzasadnienie nie tylko obecności Słowian rozproszonych na mapie pokongresowej Europy, ale też która przyznałaby im prawo do podmiotowości - udziału w kulturze, w polityce, wreszcie do zasłużonego miejsca w dziejach kontynentu. Po kongresie wiedeńskim i kolejnych, dławionych wiosnach ludów, trzeba było wbrew politycznym okolicznościom udowodnić duchową siłę plemion, żyjących na marginesie europejskiej cywilizacji. Zofia Stefanowska pisała wprost o ówczesnej sytuacji: „Słowianie byli trzecim światem Europy" (Stefanowska 289).

Tę znaczącą niewspółmierność diagnozował w latach czterdziestych w prelekcjach paryskich Adam Mickiewicz. Wiedział od Johanna Gottfrieda Herdera, że w przeciwieństwie do opanowanej powierzchni geograficznej, Słowianie zajmują najmniej miejsca w historii (Herder 324). Nie podzielał jednak przekonania filozofa wyrażonego w księdze szesnastej drugiego tomu Myśli o filozofii dziejów, że w ich przypadku chrześcijaństwo stało się elementem zniewolenia i wyzysku, a także 
instrumentem wykorzenienia z przyrodzonych właściwości charakteru³ . Wbrew sądom luterańskiego pastora, polski poeta poprzez swoją wizję dziejów, roztaczaną z paryskiej katedry literatury, ukazywał potencjał i rolę, jaką narody podbite przez monarchów europejskich odgrywały w przeszłości i łączył ją jednoznacznie z chrztem. Jako argument wykorzystywał pamięć o ludowych zwyczajach i baśniową przeszłość przechowaną w literaturze tworzonej nad Wisłą, Wełtawą i Dunajem.

Odwołując się do przeszłości Słowian, Mickiewicz przepowiadał rolę, jaką mogą oni odegrać na kontynencie w przyszłości ${ }^{4}$. Poeta był absolwentem znakomitego wówczas Uniwersytetu w Wilnie (ośrodka nauki i myśli oświeceniowej, ale też miejsca wykładów nowoczesnej historii Joachima Lelewela) oraz przenikliwym obserwatorem przemian zachodzących w kulturze europejskiej. Jako romantyk wiedział, że warunkiem myślenia o samodzielności narodu był formułowany przez Maurycego Mochnackiego w przeddzień wybuchu powstania listopadowego postulat „uznania samego siebie w swoim jestestwie” (Mochnacki 212). Romantyczny krytyk w rozprawie O literaturze polskiej $w$ wieku dziewiętnastym stwierdzał, że istotą podmiotowości ludzkiej i narodowej jest refleksja, samopoznanie. Pisał: „niemała to rzecz być musi uznanie samego siebie w jestestwie swoim, przez to jedynie człowiek staje się refle ksj a natury, reprezentantem całego przyrodzenia i wszystkich na świecie stworzeń. Ale ten tytuł zaszczytny służy tylko myślącym, rozumują cy m ludziom, w których myśli zgromadzone są wszystkie po całym przyrodzeniu, roztrącone błyski to życia, to rozeznawań” (Mochnacki 212).

Mickiewicz na paryskiej katedrze stawał się jakby ucieleśnieniem tej refleksji, formułował bowiem w imieniu wszystkich Słowian ich własne racje dziejowe. Nadawał sens ich przeszłości. Wobec paryskich słuchaczy podkreślał, że narody te ujawnią swoje znaczenie w przyszłości: „Ród słowiański sam jeszcze nie ma świadomości swych przeznaczeń. [...] Nie przyszedł nawet jeszcze czas powiedzieć wszystko o Słowianach. Najważniejsze tajemnice narodowe chowa Opatrzność na stanowczą chwilę działania" (Mickiewicz 11: 328).

Kreśląc dzieje literatur, które były słabo znane na Zachodzie Europy, polski emigrant projektował jednocześnie przyszły porządek kontynentu. Jego najważniejszym czynnikiem miała być duchowość, charakterystyczna dla rodziny narodów

${ }^{3}$ „Czy można się dziwić, że po wiekach ujarzmienia, rozgoryczenia wobec swoich chrześcijańskich panów i rabusiów, ich miękki charakter przemienił się w chytrą, okrutną niewolniczą bierność. A przecież wszędzie, a zwłaszcza w krajach, w których korzystali z pewnej wolności, odnajdujemy jeszcze cechy ich dawnego charakteru" (Herder 327). Na temat koncepcji religii Herdera zob. Starzyńska-Kościuszko.

${ }^{4} \mathrm{Na}$ temat podobieństwa w ujmowaniu roli Słowian Wojtyły i Mickiewicza pisze Dziedzic: „Łączyło ich zresztą znacznie więcej - m.in. fascynacja tematyką słowiańską i wiara w historyczne posłannictwo, które przypadnie Słowianom odegrać w dziejach świata" (Dziedzic 320). 
słowiańskich, a zagubiona przez zapatrzone w postęp naukowy i techniczny narody zachodnie. Poeta wprost definiował kryzys ideowy panujący w ówczesnym świecie i werbalizował powszechne oczekiwanie na przełom polityczny i kulturowy5.

Wypowiadane na emigracji słowa powodowały ferment w umysłach uczestników prelekcji i oczywiście budowały mit słowiańskiego wieszcza. Były także wyzwaniem dla słuchających Mickiewicza Polaków ${ }^{6}$. Konieczność nowej definicji rzeczywistości po powstaniu listopadowym i wymóg narodowej autorefleksji nie były przecież powszechne wśród emigracji, pozbawionej nadziei, niejednokrotnie znużonej i intelektualnie rozleniwionej. Rozumieli to najwięksi poeci. Jako wezwanie do krytycznej pracy definiował własną narodowość w 1840 roku Juliusz Słowacki, oskarżając w Grobie Agamemnona współczesnych sobie Polaków o uleganie obcym wzorom i zatratę własnej tożsamości. Poeta powtarzał przestrogi poetyckich poprzedników, włączając się w długi szereg diagnostów polskiego charakteru narodowego. Czynił to, jak wiadomo, na próżno.

Podobny postulat umieszczał Cyprian Norwid w pochodzącym z 1850 roku wierszu Pieśń od ziemi naszej. Przeciwstawiał w nim Słowian innym narodom, dzieląc Europę na Wschód i Zachód, Północ i Południe. Geograficzne zróżnicowanie poddawał wartościowaniu. Zachodowi przypisywał poeta „kłamstwo-wiedzy i błyskotność”, „formalizm prawdy” i „bez-istotność” („Pieśń od ziemi naszej” 424). Wschód był dla niego siedliskiem „mądrości-kłamstwa i ciemnoty” oraz „trądu, jadu i brudu" (424). Południe cechowała skłonność do bezmyślnego poklasku, Północ - głuchota, pustka, brak znaczenia. Tak określając Europę, autor przeznaczał Słowianom rolę, która miała być efektem cierpienia, ale też uzyskanej w drodze refleksji samowiedzy. Pisał o roli, jaką mają odegrać w przyszłości: „Braterstwo ludom dam, gdy zy o s u z zę,/ Bo wiem, co wła s ność ma - co ścierpieć muszę" („Pieśń od ziemi naszej” 425).

Krytyczny pogląd na brak świadomości narodowej Polaków formułował Norwid jeszcze w czerwcu 1882 roku w wierszu Stowianin. Do Teofila Lenartowicza. U progu śmierci, schorowany, oceniał ród Słowian następująco:

Jak Słowianin, gdy brak mu naśladować kogo,

Duma, w szerokim polu, czekając na si e bi e -

Gdy z dala jadą kupcy gdzieś żelazną-drogą,

\footnotetext{
${ }^{5}$ Pisze Zofia Stefanowska: „Wielka przemiana nie będzie zniszczeniem cywilizacji zachodniej ani też pierwotnej rodzimości Wschodu, lecz przezwyciężeniem ich sprzeczności i syntezą pierwiastków wartościowych. Słowianie wniosą kulturę duchową związaną z rolniczym trybem życia, ale i osiągnięcia cywilizacji technicznej Zachodu zostaną wchłonięte przez przyszłą zintegrowaną Europę” (293).

${ }^{6}$ Chodzi m.in. o koncepcję mesjanistyczną, która budziła i budzi do dziś wiele kontrowersji, a w recepcji Karola Wojtyły zyskała ucieleśnienie jako istotny wyraz tożsamości narodowej. Na ten temat zob. Sokulski oraz Rojek.
} 
Drżą telegramy w drutach i balon na niebie;

Jak Słowianin, co chadzał już wszystkiemu w tropy,

Oczekiwa na siebie-samego, bez wiedzy. (Stowianin 645)

W cytowanym wierszu Norwid stawia przed czytelnikiem zadanie rozumienia własnej słowiańskości w obliczu przemian cywilizacyjnych zachodzących w Europie, a także wobec stereotypów, które oznaczają przynależność narodową i decydują o kształcie egzystencji. Diagnoza poety formułowana w utworze była druzgocąca. Podstawowym wymiarem nieobecności Słowian w życiu kontynentu jest wedle Norwida, tylekroć w przeszłości piętnowana, skłonność do naśladownictwa, brak intelektualnej samodzielności i oryginalności, a także duchowa abnegacja, przejawiające się w biernym czekaniu na uboczu głównych dróg europejskiego rozwoju.

Skierowany do Lenartowicza wiersz, jak przypuszczają autorki Kalendarium życia i twórczości Cypriana Norwida, miał być aluzją do objęcia przez adresata katedry literatur słowiańskich na uniwersytecie w Bolonii (Kalendarz 754), która, po czasach prelekcji Mickiewicza, od 1879 roku stała się trybuną niepodległej myśli polskiej. Niezwykle gorąco przyjmowane wykłady florenckiego wygnańca ujawniały jego poglądy na zbawienną rolę Słowian w chrześcijańskiej historii Europy. Były manifestacją siły ducha i potęgi literatury słowiańskiej. Poetyckim wyrazem zapatrywań Lenartowicza jest pochodzący z czasu bolońskich prelekcji poemat, opublikowany we Lwowie w 1881 roku. Nosi on tytuł Choragiew stowiańska do grobu św. Cyryla $w$ Rzymie. Utwór pisany jest z pozycji pielgrzyma, przedstawiciela Słowiańszczyzny w Rzymie. Lenartowicz, podobnie jak autor Pana Tadeusza, występuje w nim jako rzecznik wszystkich plemion, idealizowanych i ukazywanych jako ludy łagodne, religijne, zgodne i nieskłonne do przemocy. Ma za sobą lekcję Herdera, ale także - a może przede wszystkim - pamięć o poglądach Kazimierza Brodzińskiego, które zainicjowały refleksję nad charakterem literatury narodowej, projektowały jej kierunek rozwoju (niekoniecznie zgodny z wizjami innych poetów, np. ze szkoły ukraińskiej) i odegrały tak ważną rolę w samoocenie Polaków „lubiących sielanki””.

Obszerny tekst poematu Lenartowicza poprzedza wstęp, w którym poeta, podobnie jak cytowany wcześniej Norwid, formułuje konieczność zdobycia przez Słowian samowiedzy, która stanie się warunkiem ich wolności. Pisze:

Gdyby te Słowiany/ Raz się obaczyły,

Toby im kajdany/ Rączek nie krwawiły. (Lenartowicz 5)

${ }^{7}$ Zob. na ten temat Witkowska, Kazimierz Brodziński oraz Witkowska, Stawianie, my lubim sielanki... Projekt romantyzmu Brodzińskiego, najlepiej ukazany w rozprawie O romantyczności i klasyczności tudzież o duchu poezji polskiej, zakładał zwrot do ludowości i uczuciowości i był efektem lektury pism J.G. Herdera. Zob. Brodziński 10. 
Koncepcja Lenartowicza ugruntowana została na przekonaniu o ścisłym zespoleniu dziejów narodów słowiańskich z chrześcijaństwem. Postulowana przez niego samowiedza ma być powrotem do źródeł religijnych, do historii chrztu i ewangelizacji, w których największą rolę poeta przyznaje świętym braciom sołuńskim. W utworze padają słowa:

A niechaj nasze błogosławią rody

Najuwielbieńsi Cyryl i Metody.

Z pieśnią po drodze, bo z naszych śpiewanek

Przyszłości ludu zawiewa poranek. (Lenartowicz 8)

Lenartowicz przekonuje, że zjednoczenie Słowian powinno mieć miejsce przede wszystkim w sferze wiary. Pisze:

Jeden nasz Kościół miły Słowianinie,

A dwa obrządki w tym jednym Kościele,

Stary słowiański i rzymska łacina, (10)

i dodaje:

Niech każdy tarczę chętnie swą podejmie,

I w jedno, w jedno wciąż się serce zbiera,

w dobrego brata, w ludu bohatera.

I w jedną wiarę i w jedne miłości,

I w jeden Kościół spojon z świętych kości

W jednego ojca, w jedną matkę wiarę.

Czucia bez miary, a sprawy pod miarę. (10)

W cytowanym wierszu Lenartowicza odbija się historia literatury polskiego romantyzmu, od programowej Ody do młodości z postulatem „mierzenia sił na zamiary, nie zamiarów podług sił" począwszy, aż do koncepcji mesjańskiej roli Słowiańszczyzny, formułowanej po doświadczeniach wieku powstań i cywilizacyjnego przyspieszenia. Podstawową nauką wynikającą z doświadczeń jest dla poety ,jedna wiara” i ,jeden Kościół”, którego słowiańskimi patronami stają się święci Cyryl i Metody: „Słowak swojego apostoła szuka,/ Od Pragi ciągnie, Ołomuńca, Lwowa,/ Od Starej Nitry, miasta Światopłuka,/ Gdziekolwiek mowa brzmiała Metodowa” (Lenartowicz 9).

Nie ma świadectw znajomości wiersza Lenartowicza przez Karola Wojtyłę. Autor Lirenki nigdy nie doczekał się sławy wieszcza, potomni odmówili mu nawet miary uznanego poety. Jednak podjęty przez niego temat misji braci Cyryla i Metodego znalazł swoją realizację w myśli Jana Pawła II. Papież ujrzał w osobach i działalności świętych znakomitych patronów dla swojej wizji zjednoczenia Europy. Zobaczył w nich przede wszystkim wspólnotę kultury antycznej i słowiańskiej oraz wyraz, jak 
pisze Ryszard Łużny, uniwersalizmu chrześcijańskiego ${ }^{8}$. W tym duchu zainicjował dialog między chrześcijaństwem i prawosławiem, a także upomniał się o grekokatolików. Dokonał tym samym niemal kopernikańskiego zwrotu w rozumieniu tożsamości narodów wschodniej, środkowej i południowej Europy. Ich kultura, zapisywana często cyrylicą, dzięki Janowi Pawłowi II zyskała szansę na symboliczny powrót do Rzymu. Przełom w takim ujęciu Słowiańszczyzny oznaczał nie tylko rewolucję intelektualną. Miał swoje konsekwencje także dla historii politycznej Europy.

Przypomnienie przez Papieża braci sołuńskich można zatem traktować jako kolejny ślad zakorzenienia w myśli romantycznej. Jan Paweł II odczytał tę tradycję, odwołując się do źródeł myślenia o Słowianach - nie bez znaczenia były tu studia polonistyczne, z podkreślaną fascynacją językiem staro-cerkiewno-słowiańskim, oraz późniejsza formacja w duchu Teatru Rapsodycznego. Karol Wojtyła nie musiał więc znać wiersza Lenartowicza. Zanim temat świętych Cyryla i Metodego podjął autor Choragwi stowiańskiej do grobu św. Cyryla w Rzymie, przypomniał go i gruntownie objaśnił Mickiewicz podczas pierwszego kursu paryskich wykładów. Tłumacząc przyczyny rozłamu wewnątrz chrześcijaństwa, ukazywał w nim drogi podziałów politycznych wśród Słowian. Misja św. Cyryla i Metodego przedstawiona została przez poetę jako wyraz dążeń ewangelizacyjnych ze strony biskupów Rzymu i przejaw pragnienia jedności Kościoła.

Działalność braci sołuńskich, poprzedzająca czas schizmy wschodniej, nie kłóci się w prelekcji romantycznego poety z kulturotwórczą rolą chrześcijaństwa zachodniego. Oba porządki - wschodni i łaciński - mają dla Europy jednakowe znaczenie. Mówił Mickiewicz 26 stycznia 1841 roku: „Żale słowianofilów zarzucających, że królestwa rozerwały jedność słowiańską, wydają się bezzasadne. Jedność ta nigdy wśród Słowian nie istniała, przeciwnie, zawsze byli oni rozdzieleni. [...] Idea jedności słowiańskiej zaczęła świtać dopiero w wieku przeszłym” (Mickiewicz 9: 110). Przyjęcie chrztu nie było dla poety aktem zagłady dawnej kultury słowiańskiej, wręcz przeciwnie - dopełnieniem oczekiwania pogańskich ludów na objawienie. 6 grudnia 1842 roku padły z paryskiej katedry słowa: „Chrześcijaństwo nie zastało u Słowian pustki; miało ono nowe życie wszczepić w życie dawne” (Mickiewicz 11: 11).

Mickiewicz podkreślał dominującą cechę duchowości Słowian i przejawianą przez nich skłonność do wiary w jednego Boga. Mówił w piątym wykładzie: „Gdy badamy starożytne dzieje Słowian, uderzają nas naprzód ich pojęcia religijne. Słowianie przyjmowali istnienie Boga jedynego" (Dzieła. Wydanie rocznicowe 64). Poeta

\footnotetext{
${ }^{8}$ Lużny cytuje tekst Patronowie wspólnego dziedzictwa kontynentu europejskiego z L'Osservatore Romano, w którym tak zostaje określone głoszenie przez nich Ewangelii: ,nie zabiło, nie zniszczyło, nie eliminowało, a przeciwnie - scalało, wynosiło i podkreślało autentyczne wartości ludzkie i kulturowe, typowe dla charakteru ewangelizowanych krajów" (Łużny 75).
} 
powoływał się na archiwizowane przez literaturę ludową ślady dawnych wierzeń i zwyczajów. Wbrew zwolennikom poglądów o zniszczeniu naturalnej religijności Słowian pod wpływem chrztu twierdził, że dopiero przyjęcie do Kościoła rzymskiego pozwoliło na wytworzenie się ich prawdziwej kultury. Podążając za myślą Mickiewicza, Papież wskazywał na ścisły związek chrześcijaństwa z tożsamością słowiańską, a także na nieustanną obecność narodów wschodu i środka Europy w dziejach kontynentu.

Podobnie jak romantyczny poeta, Jan Paweł II sytuował państwowość poszczególnych pobratymczych narodów na fundamentach chrześcijańskich. Znał twórczość Słowackiego, pamiętał zapewne poemat Cypriana Norwida Wanda, w którym, jak pisze Alina Witkowska, pogańska legenda o Wandzie została przekształcona w „misterium chrześcijańskie” (Witkowska 44). W swojej twórczości poetyckiej wielekroć ukazywał zakorzenienie i umocowanie chrześcijaństwa w kulturze prasłowiańskiej. W Pamięci i tożsamości Jan Paweł II przytaczał fragment Dziejów Apostolskich (Dz 17,22-31), który odnosił się do przemówienia św. Pawła na ateńskim Areopagu. Apostoł zwracał się do pogańskich słuchaczy następująco: „Przechodząc bowiem i oglądając wasze świętości jedną po drugiej, znalazłem też ołtarz z napisem: «Nieznanemu Bogu». Ja wam głoszę to, co czcicie, nie znając" (Pamięć i tożsamość 98).

Oczywiste jest, że cytowane słowa odnoszą się nie tylko do słuchaczy św. Pawła. Ich adresatami są przede wszystkim Słowianie, czytelnicy Pamięci i tożsamości, poddawani laicyzacji, kulturowej unifikacji i wyzuwani ze swojej tożsamości. Dlatego też naturalna, wrodzona potrzeba jedynego Boga, objawiająca się nawet wśród pogan, jest tak przez Papieża podkreślana.

Jako papież-Słowianin Jan Paweł II był świadomy swego posłannictwa w dziejach Europy. Już w pierwszym po wyborze przemówieniu skierowanym do Polaków określił swoją misję. Mówił w Gnieźnie 3 czerwca 1979 roku:

Chyba na to wybrał go Chrystus, chyba na to prowadził go Duch Święty, ażeby do wielkiej wspólnoty Kościoła wniósł szczególne rozumienie tych wszystkich słów i języków, które wciąż jeszcze brzmią obco, daleko, dla ucha nawykłego do dźwięków romańskich, germańskich, anglosaskich, celtyckich. [...] Czyż Chrystus tego nie chce, czy Duch Święty tego nie rozrządza, ażeby ten Papież-Polak, Papież-Słowianin, właśnie teraz odsłonił duchową jedność chrześcijańskiej Europy, na którą składają się dwie wielkie tradycje: Zachodu i Wschodu? (Pamięć i tożsamość 98)

Wyrazem tego przekonania stało się ogłoszenie w 1980 roku w liście apostolskim Egregiae virtutis świętych Cyryla i Metodego patronami Europy, a następnie, dokładnie pięć lat po tej decyzji, opublikowanie encykliki Slavorum apostoli. Dokument stał się wykładem życia i działalności apostołów Słowian, dyskursywnym uzasadnieniem papieskiej wizji z 1980 roku oraz, przede wszystkim, mistycznym programem zjednoczenia Europy, z nadzieją na jedność Kościołów katolickiego 
i prawosławnego. Był także wyrazem dowartościowania Słowiańszczyzny, przywrócenia jej kultury do duchowej substancji Europy.

Przywołane słowa przemówienia z Gniezna świadczą, że papieska interpretacja decyzji konklawe z 16 października 1978 roku była jednoznaczna. Potwierdzała proroctwo Juliusza Słowackiego z wiersza Pośród niesnasek Pan Bóg uderza..., a także fragment z Beniowskiego, w którym poeta pisał: „Krzyż twym Papieżem jest - twa zguba w Rzymie!" (Słowacki 100) (do tego zdania Jan Paweł II żartobliwie się odwoływał). Literatura polska, ,narodzona” z Bogurodzicy, od dawna oczekiwała na słowiańskiego Piotra i wielokrotnie przepowiadała wybór Polaka na papieża (Tazbir 91-103).

W 1980 roku, jednocześnie z ogłoszeniem braci sołuńskich patronami Europy, została w Polsce wydana antologia tekstów romantycznych pod redakcją Aliny Witkowskiej, zatytułowana „,Ja, głupi Słowianin”. Była ona częścią zasłużonej serii „Biblioteka Romantyczna”. Wybitna badaczka rekonstruowała w pracy dzieje wielkiego romansu ze Słowiańszczyzną, który zdominował polską literaturę, kulturę, historiografię i filozofię w pierwszej połowie XIX wieku. Z erudycją i zaangażowaniem relacjonowała dzieje Słowian, przedstawiane przez najwybitniejszych ówczesnych myślicieli i poetów, szukających impulsów dla odnowienia europejskiej cywilizacji i w pradawnej przeszłości odnajdujących wartości narodowe oraz uniwersalne. Prezentując dwudziestowieczny kontekst idei Słowiańszczyzny, autorka antologii zapewne świadomie (by uciec od źle kojarzonego panslawizmu) rezygnowała z prób określenia jej „długiego trwania” we współczesnej literaturze i historiografii. Konstatowała anachroniczność i nieprzydatność dyskusji o „synach sławy” w naszej części kontynentu. Pisała: „A dziś są to już spory i kłopoty literackie nie mające raczej bezpośredniej styczności ze stylem myślenia o kulturze i sposobami pisania o niej. Nie czując konieczności rozrachunku ze słowiańskim drzewiej i kędyś można te początki obserwować z ciekawością dziecka, które słucha pięknej, choć trochę zagmatwanej bajki, oraz sentymentem człowieka ery przyspieszenia cywilizacyjnego dla leniwego spokoju słowiańskiej rzeki życia” (Witkowska, „Ja, głupi Słowianin” 51).

Miała rację wybitna znawczyni literatury, podkreślając aktualność tematu słowiańskiego dla romantycznego projektu tożsamości narodu, zbudowanego przez poetów i opartego na wartościach duchowych. Nie miała jednak racji, zamykając swoją refleksję na połowie wieku dziewiętnastego i opatrując ją jedynym przypisem wziętym z twórczości Mirona Białoszewskiego (,Ja, głupi Słowianin” 350-351), w którym pamięć o pradawnej Słowiańszczyźnie ginie w atmosferze powszechnego rozleniwienia i obojętności. Publikując swoje badania zapewne nie przypuszczała Alina Witkowska, że temat słowiański z impetem powróci wraz z wyborem Karola Wojtyły na Stolicę Piotrową i stanie się zarzewiem zmian w świadomości narodów i w porządku politycznym na kontynencie. Być może dlatego autorka nie zamieściła 
w swojej antologii wiersza Słowackiego Pośród niesnasków Pan Bóg uderza..., przepowiadającego wybór papieża $\mathrm{z}$ Polski. Zapewne zawarte $\mathrm{w}$ wierszu religijne oczekiwanie nie mieściło się w ówczesnej wizji Słowiańszczyzny ani w obowiązującej metodologii badań literackich.

Tytuł książki, ,,Ja, glupi Słowianin”, może wydać się nieodpowiedni, jeśli mamy w pamięci pontyfikat Jana Pawła II. Zwłaszcza że fragment wiersza został wyjęty z kontekstu dość bezceremonialnie, bez podania lokalizacji bibliograficznej. Dopiero kiedy odnajdziemy wiersz Cypriana Norwida, z którego pochodzi cytat z okładki, odczytamy zapisane w nim słowa:

wtedy cię czekam - ja, głupi Słowianin -

Zachodzie - ty!... [...]

Bo wiem, co włas ność ma - co ścierpieć muszę:

Bo już się znam. (Norwid, Stowianin 425)

Kontekst wiersza Norwida całkowicie zmienia znaczenie słów, użytych przez Witkowską jako tytuł antologii. Zamiast zgody na naiwność, poeta wyraża przecież przekonanie w skuteczność cywilizacyjnej misji Słowian i wiarę w dotarcie do samowiedzy, do „uznania się w swoim jestestwie!”. Realizacją tej wizji stał się słowiański pontyfikat Jana Pawła II. Był on świadectwem uzyskanej przez „głupiego Słowianina" wiedzy na temat własnej tożsamości i dziejowego przeznaczenia. Ujawniał przyszłą rolę zmarginalizowanych ludów Europy. Odbudowywał ich znaczenie i godność, odkrywając drogę „,w światło - gdzie Bóg”. Odnajdywał drzemiący w słowiańskiej kulturze uniwersalizm i chrześcijańską tożsamość, zachowując szacunek dla odrębności narodowej. Czy w 2020 roku potrafimy jeszcze raz sięgnąć do tego źródła i z niego uzyskać swoją słowiańską samowiedzę?

\section{BIBLIOGRAFIA}

Białoszewski, Miron. „Tysiąc lat księcia. Małe przyśnicie z całości tysiąca lat wszystkich ludzi narodu polskiego”. Alina Witkowska. ,Ja, glupi Stowianin”. Wydawnictwo Literackie, 1980.

Brodziński, Kazimierz. O klasyczności tudzież o duchu poezji polskiej. Nakładem Krakowskiej Spółki Wydawniczej, 1920.

Dybciak, Krzysztof. Karol Wojtyla a literatura. Biblos, [b.r.w.].

Bobrownicka, Maria, Lucjan Suchanek i Franciszek Ziejka. Współcześni Słowianie wobec własnych tradycji i mitów. Sympozjum w Castel Gandolfo 19-20 sierpnia 1996. Universitas, 1997.

Dziedzic, Stanisław. „Pieśń nie przebrzmiała. Juwenilia Karola Wojtyły”. Pisarstwo Karola Wojtyły - Jana Pawła II w oczach krytyków i uczonych. Antologia, oprac. Krzysztof Dybciak, PIW, 2019, ss. $307-329$.

Halkiewicz-Sojak, Grażyna. „Rapsod i rapsodyczność w dykcji poetyckiej i refleksji Cypriana Norwida i Karola Wojtyły". Pisarstwo Karola Wojtyly - Jana Pawła II w oczach krytyków i uczonych. Antologia, oprac. Krzysztof Dybciak, PIW, 2019, ss. 265-274. 
Herder, Johann Gottfried. Myśli o filozofii dziejów. Przeł. Jerzy Gałecki. Wstępem i komentarzem opatrzył Emil Adler, t. 2, PWN, 1962.

Jan Paweł II. Pamięć i tożsamość. Rozmowy na przełomie tysiącleci. Znak, 2005.

Jan Paweł II, Pielgrzymki do Ojczyzny 1979-1983-1987-1991-1995-1997. Przemówienia, homilie. Znak, 1997.

Kalendarz życia i twórczości Cypriana Norwida, t. 2: 1861-1883, oprac. Zofia Trojanowiczowa i Elżbieta Lijewska przy współudziale Małgorzaty Pluty, Wydawnictwo Poznańskie, 2007.

Lenartowicz, Teofil. „Chorągiew słowiańska do grobu św. Cyryla w Rzymie”. Teofil Lenartowicz. Choragiew stowiańska do grobu św. Cyryla w Rzymie. Nakładem Drukarni Ludowej pod zarządem St. Baylego, 1881.

Łużny, Ryszard. Myśl stowiańska Jana Pawła II. Zbiór artykułów, red. Jan Orłowski, Anna Woźniak, Wydawnictwo KUL, 2008.

Maciejewski Jarosław. „Karol Wojtyła i Jan Paweł II wobec literatury”. Pisarstwo Karola Wojtyły Jana Pawła II w oczach krytyków i uczonych. Antologia, oprac. Krzysztof Dybciak, PIW, 2019, ss. 116-146.

Mickiewicz, Adam. Dzieła, t. 8: Literatura słowiańska. Kurs pierwszy. Tłum. Leon Płoszewski, oprac. Julian Maślanka, Czytelnik, 1997.

Mickiewicz, Adam. Dzieła, t. 11: Literatura słowiańska. Kurs trzeci i czwarty. Przeł. Leon Płoszewski, Czytelnik, 1955.

Mickiewicz, Adam. Dzieła. Wydanie rocznicowe 1978-1998, t. 8: Literatura słowiańska. Kurs pierwszy, Czytelnik, 1997.

Mickiewicz, Adam. Dzieła. Wydanie rocznicowe 1978-1998, t. 9: Literatura slowiańska. Kurs drugi, Czytelnik, 1997.

Mochnacki, Maurycy. „O literaturze polskiej w wieku dziewiętnastym”. Maurycy Mochnacki. Rozprawy literackie, oprac. Mirosław Strzyżewski, Ossolineum, 2000.

Norwid, Cyprian. „Pieśń od ziemi naszej”. Cyprian Kamil Norwid. Pisma wybrane. Wybrał i objaśnił Juliusz W. Gomulicki, t. 1: Wiersze, PIW, 1983.

Norwid, Cyprian. Stowianin. Cyprian Kamil Norwid. Pisma wybrane. Wybrał i objaśnił Juliusz W. Gomulicki, t. 1: Wiersze, PIW, 1983.

Pisarstwo Karola Wojtyły - Jana Pawła II w oczach krytyków i uczonych. Antologia, oprac. Krzysztof Dybciak, PIW, 2019.

Przybylska, Agata. „Źródła mistyki «Poezji i dramatów»”. Pisarstwo Karola Wojtyły - Jana Pawła II w oczach krytyków i uczonych. Antologia, oprac. Krzysztof Dybciak, PIW, 2019, ss. 178-195.

Rojek, Paweł. „Liturgia dziejów. Jan Paweł II i polski mesjanizm” [fragmenty]. Pisarstwo Karola Wojtyły - Jana Pawła II w oczach krytyków i uczonych. Antologia, oprac. Krzysztof Dybciak, PIW, 2019, ss. 745-756.

Rymkiewicz, Jarosław Marek. Wieszanie. Sic!, 2007.

Smaszcz, Waldemar. Stowo poetyckie Karola Wojtyły. Instytut Wydawniczy PAX, 1998.

Słowacki, Juliusz. Beniowski. Juliusz Słowacki. Dzieła wybrane, red. Juliusz Kleiner, II, Ossolineum, 1974.

Sokulski, Michał. „Echa mesjanizmów: sarmackiego i romantycznego w wizji polskich dziejów Karola Wojtyły (,Jeremiasz”) - Jana Pawła II” (Homilie z pielgrzymek do ojczyzny). Pisarstwo Karola Wojtyly - Jana Pawła II w oczach krytyków i uczonych. Antologia, oprac. Krzysztof Dybciak, PIW, 2019, ss. 720-744.

Starzyńska-Kościuszko, Ewa. „Koncepcja ludzkiej religii Johanna Gottfrieda Herdera”. Humanistyka i Przyrodoznawstwo, nr 10, 2004, ss. 81-87.

Stefanowska, Zofia. „Legenda słowiańska w prelekcjach paryskich”. Zofia Stefanowska. Próba zdrowego rozumu. Oficyna Wydawnicza Rytm, 2001.

Szymański, Wiesław Paweł. Z mroku korzeni. (O poezji Karola Wojtyty). Kalwaria Zebrzydowska, 1989. 
Taras, Bożena. „Motywy słowiańskie w poezji Karola Wojtyły”. Znaleźć źródło. Twórczość literacka Karola Wojtyly - Jana Pawta II, red. Zbigniew Andres, Jolanta Pasterska, Wydawnictwo Uniwersytetu Rzeszowskiego, 2005, ss. 63-81.

Tazbir, Janusz. „Proroctwa o polskim papieżu”. Nauka, nr 3, 2005, ss. 91-103.

Weintraub, Wiktor. „Prelekcje paryskie jako profesja”. Wiktor Weintraub. Poeta i prorok. Rzecz o profetyzmie Mickiewicza. PIW, 1982.

Witkowska, Alina. Kazimierz Brodziński. PIW, 1968.

Witkowska, Alina. Sławianie, my lubim sielanki... Państwowy Instytut Wydawniczy, 1972.

Witkowska, Alina. ,Ja, głupi Stowianin”, Biblioteka Romantyczna. Wydawnictwo Literackie, 1980.

\author{
„ZA NIM ROSNĄCE PÓJDĄ PLEMIONA / \\ W ŚWIATŁO - GDZIE BÓG". \\ „SŁOWIAŃSKI” PONTYFIKAT ŚW. JANA PAWŁA II
}

Streszczenie

Artykuł podejmuje obecność problematyki słowiańszczyzny w myśli i twórczości Jana Pawła II jako wyraz zakorzenienia w polskiej literaturze romantycznej. Jej centrum jest kult św. Cyryla i Metodego, który stał się w ujęciu Papieża wyrazem uniwersalizmu, dziedzictwa greckiego oraz chrześcijaństwa narodów słowiańskich. Przypomnienie znaczenia braci sołuńskich miało miejsce już w paryskich prelekcjach Adama Mickiewicza oraz w zapomnianym wierszu Teofila Lenartowicza. Wiązało się z koniecznością uzyskania przez Słowian samopoznania, którego domagali się Norwid, Słowacki, Mickiewicz i inni. Misja słowiańskiego Papieża realizuje powyższe postulaty romantycznych poetów. Jan Paweł II przypomina tożsamość Słowian i ich rolę dla papiestwa i w zjednoczonej Europie. Przywraca im godność. Stanowi wskazanie na przyszłość.

Słowa kluczowe: Słowianin; słowiańszczyzna; papiestwo; św. Cyryl i Metody; romantyzm

\author{
"THE GROWING TRIBES WILL FOLLOW HIM / \\ INTO THE LIGHT - WHERE THERE IS GOD": \\ THE "SLAVIC" PONTIFICATE OF ST. JOHN PAUL II
}

\title{
Sum mary
}

This article deals with the presence of issues of Slavdom in the thoughts and works of John Paul II as an expression of their roots in Polish Romantic literature. Its centre is the cult of St. Cyril and St. Methodius, who, in the Pope's view, became an expression of the universalism, Greek heritage and Christianity of the Slavic peoples. A reminder of the importance of the Solon brothers had already been mentioned in the Paris lectures of Adam Mickiewicz and in a forgotten poem by Teofil Lenartowicz. This was associated with the need for Slavs to gain self-knowledge, as demanded by Norwid, Słowacki, Mickiewicz and others. The mission of the Slavic Pope fulfils the above postulates of the Romantic poets. John Paul II recalls the identity of the Slavs and their role in the papacy and a united Europe. It restores their dignity and is an indication of their future.

Keywords: Slav; Slavdom; papacy; Saints Cyril and Methodius; Romanticism 